\title{
The Influence of Perceived Usefulness, Perceived Ease of Use, Attitude, Subjectif Norm, and Perceived Behavioral Control to Actual Usage Psak 45 Revision on 2011 with Intention as Intervening Variable in Unair Financial Departement
}

\author{
Erina Sudaryati ( $\left(1^{\text {st }}\right.$ Author $)$ \\ Accounting Department of Airlangga University Surabaya
}

\author{
Dian Agustia (2 ${ }^{\text {nd }}$ Author) \\ Accounting Department of Airlangga University Surabaya \\ Muhammad 'Illiyun Syahputra ( $3{ }^{\text {rd }}$ Author) \\ Accounting Department of Airlangga University Surabaya
}

\begin{abstract}
This study aims to determine why someone using PSAK No. 45 of 2011 on the revision of non-profit organizations. This study combines the Theory of Planned Behavior (TPB) with the Technology Acceptance Model (TAM) with variables such as the perceived usefulness, perceived ease of use, attitude, subjective norm, perceived behavioral control, intention and actual behavior to use PSAK 45. The sampling technique used is saturated sample or census. The collected data is then processed using the Smart PLS application 2.0.
\end{abstract}

Hypothesis testing results thats, perceived useulness and perceived ease of use significantly influence to the attitudes, attitude insignificantly influence to intention, subjective norms and perceived behavioral control significantly influence to intention, intention significantly influence to actual behavior, attitude can not mediate the influence of perceived usefulness and perceived ease of use to intention, intention can not mediate influence of attitude to actual behavior, intention can mediate the influence of subjective norms and perceived behavioral control to actual behavior.

Keywords: PSAK 45 revisions in 2011, perceived usefulness, perceived ease of use, attitude, subjective norm, perceived behavioral control, intention, and actual behavior

\section{INTRODUCTION}

Education has a very important role for the realization of life society more prosperous future. The existence of the university in the midst of the community is essential to support development of education itself. Given the scale of the functions of education, government support the education in Indonesia with provide a large portion of the Indonesian Budget (APBN) for education sector. At least 20 percent of the Indonesian Budget (APBN) should provided for this sector.
The university certainly needed a means of accountability according to create an entity's financial statements were relevant, reliable, can be compared, and consistent (Soetedjo 2009:24).

The University is one of the forms of organization in the running business processes do not have orientation for profit so it usually called The Non-Profit Organization (Martin and West 2003:186). In addition, the non-profit entities must consistent in doing service to the public (Salomon in Carman et al. 2008:6). Therefore, the university uses PSAK No. 45 to reporting their financial statement.

The willingness of university employees to use PSAK 45 as a base to prepare financial statements can be explained by Theory of Reason Action (TRA) enhanced be Theory of Planed Behaviour (TPB), and then developed into Technology Acceptance Model (TAM).

This study will investigate the source reason of Airlangga University (Unair) financial department employees to accept PSAK 45 revisions in 2011 as the basis for the preparation of the university's financial statements.

\section{LITERATURE REVIEW}

PSAK No. 45 revisions in 2011 is a tool to support financial accountability for any activity does for Non-profits entities (Bastian, 2007: 84). The non-profit entities is organization whose resources come from contributions of members and other contributors who do not expect a reward or payback in the form of what also (Ibrahim and Hand, 2009: 184). The financial statements based on PSAK No. 45 revisions in 2011 consisted of Statements of Financial Position, Statement of Activity, and Statement of Cash Flows and Notes to Financial Statements which is different with financial statements prepared by business organizations (IAI, 2011:45.3). 
TRA explains that the intention is the closest antecedent once the main trigger of the real behavior displayed by someone (Mulya, 2009:10). While the intention itself is affected by the attitude and subjective norm perceived by the individual.

TRA is not appropriate when used to predict spontaneous behavior, desired habit, it is set, or less excited. This matter due to such behavior is not done voluntarily and done without or less intention of the perpetrator (Dreana 2012: 14). Then put the three decisive intention to the model which is the distinguishing factor between the TRA with $\mathrm{TPB}$, these factors are perceived behavioral control (Achmat 2010:3).

TAM is widely used to predict acceptance of a person against a tool, more often this theory applied to the application of information systems (Chuttur 2009: 17). TAM said that factors that can predict the receipt of a tool is perception usefulness and perceived ease of use.

Saade, et al (2008) said that perceived ease of use does not affect the attitude, but the perceived usefulness. While the perceived usefulness influence on attitudes and not directly affects to the intention. Attitude, subjective norm, perceived behavioral control affect the intention, but the intention not affect the real behavior. He added that the intention variable may mediate the effect of attitude, subjective norm, perceived control the behavior of the actual behavior.

Sulistiyarini (2013) said that the perceive usefulness and perceived ease of use influence the attitudes, while the attitudes and subjective norms affect the intention, but the perceived behavior control not effect to intention. Ernawati and Purnomosidhi (2012) said that the attitude and perceived behavior control affects the intention, but subjective norm does not. Besides, the perception of behavioral control have direct effect on the actual behavior. Then intention also affect the real behavior. Intention could mediating between influence of attitude, subjective norm, and perceived behavioral control against actual behavior.

The framework of this study adopted a research model do Sulistiyarini (2013: 5) as follows:

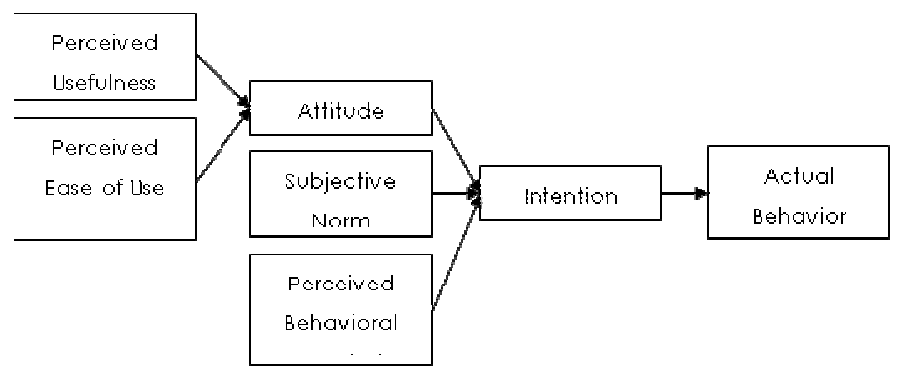

Figure 1. Research Framework

And the the hypothesis of this study as follow in table 1 below:
Table 1. Research Hypothesis

\begin{tabular}{|l|l|}
\hline \multicolumn{2}{|c|}{ Hiotesis Penelitian } \\
\hline H1 & Perceived usefulness influence attitude. \\
\hline H2 & Perceived ease of use influence attitude. \\
\hline H3 & Attitude influence intention. \\
\hline H4 & Subjective norm influence intention. \\
\hline H5 & Perceived behavioral control influence intention. \\
\hline H6 & Intetion influence actual behavior. \\
\hline H7 & $\begin{array}{l}\text { Attitude can mediate the influence of perceived } \\
\text { usefulness to intention. }\end{array}$ \\
\hline H8 & $\begin{array}{l}\text { Attitude can mediate the influence of perceived ease } \\
\text { of use to intention. }\end{array}$ \\
\hline H9 & $\begin{array}{l}\text { Intention can mediate the influence of attitude to } \\
\text { actual behavior. }\end{array}$ \\
\hline H10 & $\begin{array}{l}\text { Intention can mediate the influence of subjective } \\
\text { norm to actual behavior. }\end{array}$ \\
\hline H11 & $\begin{array}{l}\text { Intention can mediate the influence of perceived } \\
\text { behavioral control to actual behavior. }\end{array}$ \\
\hline
\end{tabular}

\section{Research Method}

Operational Definition

a. Perceived Usefulness (X1).

Santoso (2010: 29) said that this variable indicates the degree of respondents believed that using the PSAK 45 revisions in 2011 will be improve their work quality. The indicators to measure were adoptied from Morris and Dillon (1997) in Santoso (2010: 29) with the opinion of the respondents who stated that by using the revised PSAK 45 can improve the quality of financial reporting, saving time for the preparation of financial statements, improve skills in preparing the financial statements, have an accurate basis for the preparation, support good accountability, generate transparent financial statements and provide added value for itself in terms of preparing the financial statements of the entity.

\section{b. Perceived Ease of Use (X2).}

Lestari (2013: 25) said that this variable indicates the level of confidence of respondents that use the PSAK 45 revised in 2011 is easy to use. The indicators to measure were adoptied of Davis (1989) in Lestari (2013: 25) with the opinion of the respondents who stated that implement is an easy thing, any rules that are loaded easily understood, giving complete information to the university's financial report fairly, language / sentences used easy to understand, there is no paragraph that has a multi interpretation, and he had no trouble when mengimplentasikannya.

c. Attitude (X3).

Dreana (2012), quoted Lu, et al (2010) define the attitude as an evaluation of confidence if it should display a 
desired behavior. Measured with the opinion of the respondents who stated that the PSAK 45 revised in 2011 is accordance with the characteristics of the entity, has enough complexity rules, the absence of any other standar accordance with the entity, the use of an effort to create accountability in the entity, such use is a demand profession, he must understand the standards accounting or financial rules that others who are not regulated in that PSAK, he must adjust the process of drafting the computerized accounting application with the rules of PSAK 45 revisions in 2011, and he also had to understand the special accounts that only exist in the PSAK 45 revised in 2011.

\section{d. Subjective norm (X4).}

Agustiantono (2012) and Mutikasari (2007), quoted Ajzen (1988) which defines the subjective norm with the perception of the individual will be social influence in shaping behavior. It measured with the opinion of respondents stated that the influence of co-workers, management, government or related agencies that he uses PSAK 45 revisions in 2011 as the basis for preparing financial statements.

\section{e. Perceived Behavioral Control (X5).}

Perceived Behavioral Control by Ajzen (1991) is a convenient or perceived difficulty to display a behavior (Dreana, 2012:40). Measured with the opinion of the respondents who stated that the use of the PSAK 45 revised in 2011 is a form of consciousness to use appropriate standards, a form of responsibility to generate quality financial statements, it can facilitate the process of accountability, as it supports the principles of transparency, to cultivate financial report standardization, entity has been providing computerized accounting application in accordance with the rules of PSAK 45 revision in 2011, the entity has to provide standards and other rules regarding matters that are not regulated in PSAK 45 revision in 2011, and the entity has well conducted education and training to prepare financial statements using the PSAK 45 revision in 2011.

\section{f. Intention (Y1).}

This variable shows how big and hard effort for someone to display a behavior. Harinurdin (2009:97) and Jayanto (2011:57) said that the intention of variables can be measured with a tendency to behave and the decisions that will be displayed showing a behavior by a person to use PSAK 45 revision in 2011.

\section{g. Actual Behavior (Y2).}

This variable indicates acceptance for the use of PSAK 45 revisions in 2011 as the basis in preparing the financial statements. Santoso (2010:31) using indicators derived from AL-Gahtani and King (1999), then Shih and Huang (2009: 269) adds an indicator the frequency of use in research.

\section{Data Collection Procedures}

a. Population and Sample Research

Population of this research is that an employee who works in the finance department Unair. The sampling technique used by researchers is saturated or census sampling. Sugiyono (2011) states that this technique is used to sample the population is relatively little or researcher wants to make generalizations with a small error.

\section{b. Data Collection Technique}

Collecting data in this study using a research instrument in the form of a questionnaire wich distributed to respondents. Type questionnaire used is closed questionnaire, i.e. questionnaire predetermined alternative answers to each question posed above statement. The questionnaires used adopted from Agustiantono (2012) and Mustikasari (2007) research.

\section{c. Testing Instrument Research}

Before conducting an analysis of the data have been obtained from the respondents, first testing the validity and reliability of the data that has been obtained. Testing the validity of using discriminant validity and reliability using composite reliability will be discussed at the inner test models.

\section{d. Data Analysis Tool}

Analysis of the data in this study using a model of Structural Equation Model (SEM) based component or variance or better known as the model of Partial Least Square (PLS) with PLS 2.0 Smart Software.

Significance criteria performed by comparing the calculation results $t_{\text {statistic }}$ with $t_{\text {table }}$. If $t_{\text {statistic }}>t_{\text {table, the }}$ research revealed a significant influence between independent variable on the dependent variable. Hypothesis testing can be done through the mediation Sobel test, by testing the strength of the indirect effect of independent variables $(\mathrm{X})$ to the dependent variable $(\mathrm{Y})$ through an intervening variable $(\mathrm{M})$.

\section{e. Hypothesis Testing}

Hypothesis testing is done using two models, namely the outer and inner models models. Outer models measure how far the indicators that can explain the latent variables. Reflective indicators tested by convergent validity, discriminant validity or the Average Variance Extracted (AVE) and composite reliability.

Structural model is then evaluated in inner models using $\mathrm{R}^{2}$ to construct dependent, Stone-Geisser $\mathrm{Q}^{2}$ test for predictive relevance and t-test and significance and coefficient parameters of structural lines. The relationship between the value of predictive relevance with R2 formulated as follows: $\mathrm{Q}^{2}=1-\left(1-R_{\text {Attitude }}^{2}\right)(1-$ $\left.R_{\text {Intention }}^{2}\right)\left(1-R_{\text {ACtual Behavior }}^{2}\right.$. 


\section{RESULTS AND DISCUSSION}

Estimates Outer Measurement Model

The minimum threshold value of outer loading factor an indicator that declared eligible to reflect a variable of 0.5 . Structural model used in this study can be seen in Figure 2 below:

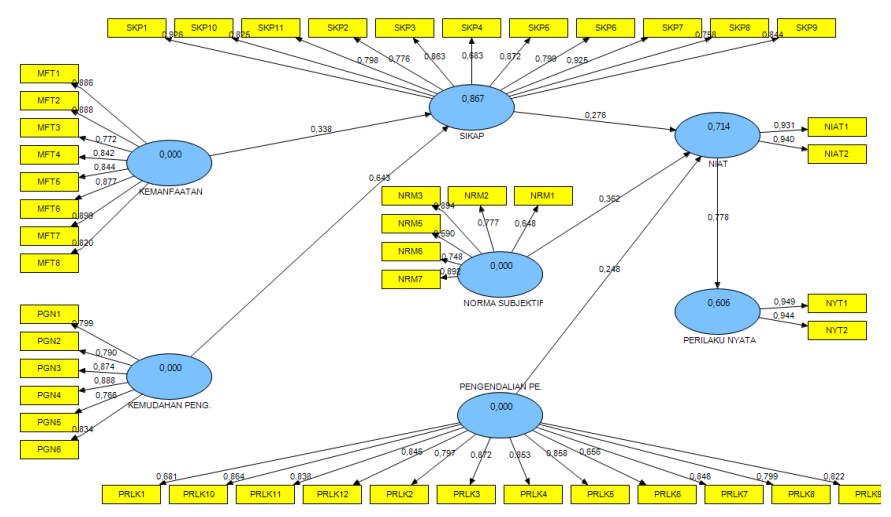

Source: Data Processed, 2015.

Figure 2. Figure 2 Outer Iteration Results Loading Factor

After all proxy feasible, reliability testing performed by compositing reliability of the block indicator that measures the construct. Otherwise construct composite reliability reliable if the value above 0.70 as table 2 below:

Table 2. Composite Reliability

\begin{tabular}{|l|c|}
\hline \multicolumn{1}{|c|}{ Variable } & Composite Reliability \\
\hline Perceived Usefulness & 0,9557 \\
\hline Perceived Ease of Use & 0,928 \\
\hline Attitude & 0,9595 \\
\hline Subjective Norm & 0,8932 \\
\hline Perceived Behavioral Control & 0,959 \\
\hline Intention & 0,9335 \\
\hline Actual Behavior & 0,9452 \\
\hline
\end{tabular}

Source: Data Processed, 2015.

\section{Estimates Measurement of Inner Model}

In this study, there are three endogenous variables, ie attitudes, intentions, and real behavior. R-square value $\left(\mathrm{R}^{2}\right)$ of each of the endogenous variables are presented in Table 3 below:

Table 3. The value of R-Square $\left(\mathrm{R}^{2}\right)$

\begin{tabular}{|c|c|}
\hline Variabel Endogen & Nilai $^{2}$ \\
\hline Attitude & 0,8669 \\
\hline Intention & 0,7138 \\
\hline Actual Behavior & 0,6056 \\
\hline
\end{tabular}

Source: Data Processed, 2015.
Based on the table 4.12, it is known that the $\mathrm{R}^{2}$ value of the variable attitude of 0.8669 , which means that these variables can be explained by $86.69 \%$ by the variable perceived usefulness and perceived ease of use. Then variable intention of 0.7138 , which means that these variables can be explained by $71.38 \%$ by the perceived usefulness, perceived ease of use, attitudes, subjective norms, and perceived behavioral control. Then the variable actual behavior of 0.6056 , which means that these variables can be explained by $60.56 \%$ by the perceived usefulness, perceived ease of use, attitude, subjective norm, perceived behavioral control, and intention.

To see all relationship of the variables in a system built on this research, then do calculate predictive relevance $\left(Q^{2}\right)$ with the following formula:

$\mathrm{Q}^{2}=1-\left(1-R_{\text {Attitude }}^{2}\right)\left(1-R_{\text {Intention }}^{2}\right)(1-$

$\left.R_{\text {Actual Beavior }}^{2}\right)$

$\mathrm{Q}^{2}=1-(1$ - 0,8669) (1 - 0,7138) $(1$ - 0,6056)

$\mathrm{Q}^{2}=1-(0,1331)(0,2862)(0,3944)$

$\mathrm{Q}^{2}=1-0,015023965968$

$\mathrm{Q}^{2}=0,984976034032$

$\mathrm{Q}^{2}$ values obtained at 0.984976034032 . This indicates that the model can explain the phenomenon of organized influence the perceived usefulness, perceived ease of use, attitude, subjective norm, perceived behavioral control, and the intention of the actual behavior using PSAK 45 revisions in 2011 of $98.5 \%$. While the remaining $1.5 \%$ is explained by other variables not examined in this study.

Proof Hypothesis

Statistical Testing Table 4 shows the results as follows:

Table 4. Results of Testing Direct and Indirect Influence

\begin{tabular}{|c|c|c|c|c|c|}
\hline $\begin{array}{c}\text { Ralation Between } \\
\text { Variables }\end{array}$ & $\begin{array}{c}\text { Original } \\
\text { Sample } \\
(\mathrm{O})\end{array}$ & $\begin{array}{c}\text { Standard } \\
\text { Error } \\
(\text { STERR })\end{array}$ & $\begin{array}{c}\text { T Statistics } \\
(\mid \text { O/STERR })\end{array}$ & $\begin{array}{c}\text { Standar } \\
\text { Error } \\
(\text { Sab })\end{array}$ & $\begin{array}{c}\text { Sobel } \\
\text { Test }\end{array}$ \\
\hline $\begin{array}{c}\text { Perceived } \\
\text { Usefulness } \\
\text { Attitude }\end{array}$ & 0,3384 & 0,0799 & 4,2365 & - & - \\
\hline
\end{tabular}

\begin{tabular}{|c|c|c|c|c|c|}
\hline $\begin{array}{c}\text { Ralation Between } \\
\text { Variables }\end{array}$ & $\begin{array}{c}\text { Original } \\
\text { Sample } \\
(\mathrm{O})\end{array}$ & $\begin{array}{c}\text { Standard } \\
\text { Error } \\
(\text { STERR })\end{array}$ & $\begin{array}{c}\text { T Statistics } \\
(\mid \text { O/STERR })\end{array}$ & $\begin{array}{c}\text { Standar } \\
\text { Error } \\
(\text { Sab })\end{array}$ & $\begin{array}{c}\text { Sobel } \\
\text { Test }\end{array}$ \\
\hline $\begin{array}{c}\text { Perceived Ease of } \\
\text { Use } \rightarrow \text { Attitude }\end{array}$ & 0,6425 & 0,0784 & 8,2 & - & - \\
\hline $\begin{array}{c}\text { Attitude } \rightarrow \\
\text { Intention }\end{array}$ & 0,2756 & 0,1357 & 2,0313 & - & - \\
\hline $\begin{array}{c}\text { Subjective Norm } \\
\rightarrow \text { Intention }\end{array}$ & 0,3625 & 0,1096 & 3,3069 & - & - \\
\hline $\begin{array}{c}\text { Perceived } \\
\text { behavioral control } \\
\rightarrow \text { Intention }\end{array}$ & 0,2479 & 0,0817 & 3,0349 & - & - \\
\hline $\begin{array}{c}\text { Intention } \rightarrow \\
\text { Actual Behavior }\end{array}$ & 0,7782 & 0,036 & 21,6319 & - & - \\
\hline $\begin{array}{c}\text { Perceived } \\
\text { usefulness } \rightarrow \\
\text { Attitude } \rightarrow \\
\text { Intention }\end{array}$ & 0,0933 & - & - & 0,0521 & 1,7911 \\
\hline
\end{tabular}




\begin{tabular}{|c|c|c|c|c|c|}
\hline $\begin{array}{c}\text { Perceived ease of } \\
\text { use } \rightarrow \text { Attitude } \rightarrow \\
\text { Intention }\end{array}$ & 0,1771 & - & - & 0,0904 & 1,9576 \\
\hline $\begin{array}{c}\text { Attitude } \rightarrow \\
\text { Intention } \rightarrow \\
\text { Perilaku Nyata }\end{array}$ & 0,2145 & - & - & 0,1062 & 2,0199 \\
\hline $\begin{array}{c}\text { Subjective norm } \\
\rightarrow \text { Intention } \rightarrow \\
\text { Actual Behavio }\end{array}$ & 0,2821 & - & - & 0,0864 & 3,266 \\
\hline $\begin{array}{c}\text { Perceived } \\
\text { behavioral control } \\
\rightarrow \text { Intention } \rightarrow \\
\text { Actual Behavio }\end{array}$ & 0,1929 & - & - & 0,0643 & 3,0017 \\
\hline
\end{tabular}

Source: Data Processed, 2015.

\section{Discussion}

Hypothesis testing results showed that $\mathrm{H} 1$ and $\mathrm{H} 2$ are supported. The finding implies that the perceived usefulness and perceived ease of use in the use of PSAK 45 revision in 2011 affect its attitude on the use of PSAK 45 revisions in 2011 and to support research Bugembe (2010), Sulistyarini (2013), Ngai et al (2007), Istiarni and Hadiprajitno (2014), Saade, et al (2008), Tangke (2004), Latifah and Afifah (2013), and Gunawan (2014).

$\mathrm{H} 3$ has not been proven a willingness to use the PSAK 45 revised on 2011 by the respondent is not influenced by his attitude on the use of the PSAK, but influenced by subjective norms (H4) and the perception of behavioral control (H5) that develops around it. These findings support research Jayanto (2011), Sulistyarini (2013), Lucyanda (2010), Saade, et al (2008), Harinurdin (2009), Agustiantono (2012), Istiarni and Hadiprajitno (2014) and Ernawati and Purnomosidhi (2012).

H6 supported which means the actual behavior shown to use PSAK 45 revision in 2011 was influenced by an intention to use it beforehand. These findings support research Harinurdin (2009), Ernawati and Purnomosidhi (2012), Jayanto (2011), and Agustiantono (2012)

Indirect influence of the tested showed that attitude can not mediate the effect of the perception of the usefulness (H7) and perceived ease of use (H8) on the intention to use the PSAK 45 revised on 2011, as well as the intention is not able to mediate the effect of attitude (H9) against actual behavior, but can mediate the effect of subjective norm (H10) and the perceived behavioral control (H11) to the actual behavior using the PSAK 45 revised on 2011.

\section{CONCLUSION}

This study shows that the perceived usefulness and perceived ease of use affects a significant effect on a person's attitude on the use of the PSAK 45 revised on 2011. However, no significant effect on the attitude of a person's desire to use the PSAK, but subjective norm and perceived behavioral control who significantly influence the desire to use that PSAK. Intention itself a significant effect on the actual behavior.

Attitude on the use of PSAK 45 revision in 2011 can not mediate the effect of perceived usefulness and perceived ease of use of the person's desire to use that PSAK, the intention was also unable to mediate the effect of attitude toward the actual behavior, but can mediate the influence of subjective norms and perceived behavioral control of the actual behavior under the use of that PSAK

\section{BIBLIOGRAPHY}

[1] Achmat, Zakaria. 2010. Theory of Planned Behavior, Masihkan Relevan?

[2] Agustiantono, Dwi. 2012. Analisis Faktor-Faktor yang Mempengaruhi Kepatuhan Wajib Pajak Orang Pribadi: Aplikasi TPB (Studi Empiris WPOP di Kabupaten Pati). Skripsi tidak diterbitkan. Semarang Fakultas Ekonomika dan Bisnis Universitas Diponegoro.

[3] Bastian, Indra. 2007. Akuntansi untuk LSM dan Partai Politik. Jakarta: Erlangga.

[4] ------, Indra. 2010. Akuntansi Sektor Publik: Suatu Pengantar. Jakarta: Erlangga.

[5] Bugembe, Juliet. 2010. Perceived Usefulness, Perceived Ease of Use, Attitude and Actual Usage of New Financial Management System: A Case Study of Uganda National Examinations Board. Desertasi tidak diterbitkan. Makerere University Business School.

[6] Carman, Joanne G. dkk. (Eds.). 2008. Government and Accountability: Paving the Way for Nonprofits and Evaluation. New Directions for Evaluation, (119): 5-12.

[7] Chuttur, Mohammad. 2009. Overview of the Technology Accaptance Model: Origins, Developments and Future Directions. Indiana University, USA. Sprouts: Working Papers on Informations Systems, 9 (37).

[8] Dewan Standar Akuntansi Keuangan. 2011. Pernyataan Standar Akuntansi Keuangan Nomor 45 tentang Pelaporan Keuangan Entitas Nirlaba. Jakarta: Ikatan Akuntan Indonesia.

[9] Dreana, Monica Tirza. 2012. Analisis Faktor-Faktor yang Mempengaruhi Penerimaan Penggunaan SIMAWEB di Fakultas Ekonomika dan Bisis Universitas Diponegoro: Integrasi TAM dan TPB. Semarang Fakultas Ekonomika dan Bisnis Universitas Diponegoro.

[10] Ernawati, Widi Dwi dan Bambang Purnomosidhi. 2010. Pengaruh Sikap, Norma Subjektif, Kontrol Perilaku Yang Dipersepsikan, dan Sunset Policy Terhadap Kepatuhan Wajib Pajak dengan iat Sebagai Variabel Intervening, (Online), (http://purnomo.lecture.ub.id/files/2012/01/Pengaruhsikap-dll-thd-kepatuhan-WP1.pdf, diakses pada 24 April 2015).

[11] Fakhrana, Rinaldy Sofwan. CNN Indonesia. 2014, 30 Oktober. Anggaran Pendidikan Diminta Dialihkan. (Online). https://www.cnnindonesia.com.

[12] Girindratama, M. Wisnu. 2014. Pengaruh Good Corporate Governance Terhadap Kinerja Perusahaan dan Corporate Social Responsibility Sebagai Variabel 
Intervening. Skripsi tidak diterbitkan. Surabaya Fakultas Ekonomi dan Bisnis Universitas Airlangga.

[13] Gunawan, Andrew. 2014. Aplikasi Technology Acceptance Model pada Minat Nasabah untuk Menggunakan Internet Banking. Jurnal Nominal, 3 (2): 55-74.

[14] Harinurdin, Erwin. 2009. Perilaku Kepatuhan Wajib Pajak Badan. Jurnal Ilmu Administrasi dan Organisasi. 16 (2): 96-104.

[15] Ibrahim, Ridwan dan Tri Handayani. 2009. Penerapan Pernyataan Standar Akuntansi Keuangan Nomor 45 pada Baitul Mal Provinsi Nanggroe Aceh Darussalam. Jurnal Telaah \& Riset Akuntansi, 2 (2): 183-197.

[16] Istiarni, Panggih Rizki Dwi dan Paulus Basuki Hadiprajitno. 2014. Analisis Pengaruh Persepsi Manfaat, Kemudahan Penggunaan dan Kredibilitas Terhadap Minat Penggunaan Berulang Internet Banking dengan Sikap Penggunaan Sebagai Variabel Intervening (Studi Empiris: Nasabah Layanan Internet Banking di Indonesia). Diponegoro Journal of Accounting, 3 (2): 2337-3806.

[17] Jayanto, Prabowo Yudo. 2011. Faktor - Faktor Ketidakpatuhan Wajib Pajak. Jurnal Dinamika Manajemen, 2 (1): 48-61.

[18] Kementerian Pendidikan dan Kebudayaan. 2015, 13 Februari. RAPBN Perubahan Kemendikbud Tahun Anggaran 2015 Disetujui, (Online). https://www.kemendikbud.go.id.

[19] Kriyantono, Rachmat. 2012. Teknik Praktis Riset Komunikasi. Jakarta: Pranada.

[20] Latifah dan Azka Nur Afifah. 2013. Pengaruh Variabel Perceived Useefulness, Perceived Ease of Use, Perceived Enjoyment, dan Attitude Terhadap Pemanfaatan Visual Hotel Program Pada Hotel-Hotel di Yogyakarta. Jurnal Riset Akuntansi Keuangan, 4 (1): 33-47.

[21] Lee, Hyun Hwa dan Eunyoung Chang. 2011. Consumer Attitudes Toward Online Mass Customization: An Application of Extended Technology Acceptance Model. Journal of ComputerMediated Communication, 16: 171-200.

[22] Lestari, Dimar Ayu. 2013. Penggunaan Technology Acceptance Model (TAM) pada Layanan Mandiri Internet Banking di Surabaya. Skripsi tidak diterbitkan. Surabaya Fakultas Ekonomi dan Bisnis Universitas Airlangga.

[23] Lucyanda, Jurica. 2010. Pengujian Technology Acceptance Model (TAM) dan Theory Planned Behaviour (TPB). Jurnal Riset Akuntansi \& Keuangan Akuntansi. 2: 1-14.

[24] Martin, Susan W. dan Ellen N. West. 2003. Today's Essentials of Governmental and Not-for-Profit Accounting and Reporting. Ohio: South-Western.

[25] Mulya, Teuku Andhika. 2009. Pengaruh Sikap, Norma Subjektif, Perceived Behavioral Control Terhadap Perilaku Menggunakan Transjakarta untuk Pergi ke Tempat Kerja melalui Intensi. Skripsi tidak diterbitkan. Jakarta Fakultas Psikologi Universitas Indonesia.

[26] Mustikasari, Elia. 2007. Kajian Empiris Tentang Kepatuhan Wajib Pajak Badan di Perusahaan
Industri Pengolahan di Surabaya. Simposium Nasional Akuntansi X, Makassar, 26-27 Juli 2007.

[27] Ngai, E.W.T., dkk. 2007. Empirical Examination of The Adoption of WebCT Using TAM. Computer and Education, 48: 250-267.

[28] Pontoh, Chenly Ribka S. 2013. Penerapan Laporan Keuangan Organisasi Nirlaba Berdasarkan PSAK No 45 pada Gereja BZL. Jurnal EMBA, 1 (3): 129-139.

[29] Prayudi, Made Arista. 2011. Persepsi Penyusun Dan Pengguna Laporan Keuangan Terhadap Penerapan Pernyataaan Standar Akuntansi Keuangan No 45 ( PSAK 45 ) Tentang Pelaporan Keuangan Nirlaba. Skripsi tidak diterbitkan. Surabaya Fakultas Ekonomi dan Bisnis Universitas Airlangga.

[30] Republik Indonesia. Undang-undang Nomor 20 Tahun 2003 tentang Sistem Pendidikan Nasional. 2003. Jakarta.

[31] Rozandy, Rizki Aditya, dkk. 2012. Analisis Variabel Variabel yang Mempengaruhi Tingkat Adopsi Teknologi dengan Metode Partial Least Square (Studi Kasus pada Sentra Industri Tahu Desa Sendang, Kec. Banyakan, Kediri). Jurnal Industri, 1 (3): 147-158.

[32] Saade, Rafaat George, dkk. 2008. Is Usage Predictable Using Belief-Attitude-Intention Paradigm?. Issues In Informing Science and Information Technology, 5: 591-599.

[33] Santoso, Budi. 2010a. Pengaruh Perceived Usefulness, Perceived Ease of Use, dan Perceived Enjoyment Terhadap Penerimaan Teknologi Informasi (Studi Empiris di Kabupaten Sragen). Tesis tidak diterbitkan. Surakarta Fakultas Ekonomi Universitas Sebelas Maret.

[34] -------, 2010b. Pengaruh Perceived Usefulness, Perceived Ease of Use, dan Perceived Enjoyment Terhadap Penerimaan Teknologi Informasi (Studi Empiris di Kabupaten Sragen). Jurnal Studi Akuntansi Indonesia, :1-15.

[35] Scott, William R. 2006. Financial Accounting Theory. Toronto: Pearson Education Canada Inc.

[36] Sekaran, Uma. 1992. Research Methods For Business: A Skill Building Approach, Secon Edition. New York: John Willey \& Sons, Inc.

[37] Sentosa, Ilham dan Nik Kamariah Nik Mat. 2012. Examining A Theory of Planned Behavior (TPB) and Technology Acceptance Model (TAM) in Internet Purchasing Using Structural Equation Modeling. Journal of Arts, Science \& Commerce, 3 (2): 62-77.

[38] Setyobudi, Wahyu T. 2008. Aplikasi Theory of Planned Behaviour (TPB) Terhadap Berbagai Pengetahuan (Knowledge Sharing) dalam Organisasi. National Conference on Management Research, Makassar, 27 November 2008.

[39] Shih, Ya Yueh dan Siao Sian Huang. 2009. The Actual Usage of ERP SystemsL An Extended Technology Acceptance Perspective. Journal of Research and Practice in Information Technology, 41 (3): 263-27.

[40] Soetedjo, Soegeng. 2009. Pembahasan Pokok-pokok Pemikiran Teori Akuntansi Vernon Kam. Surabaya: Airlangga University Press. 
[41] Sugiyono. 2011. Metode Penelitian Pedidikan (Pendekata Kuantitatif, Kualitatif, dan $R$ \& D). Bandung: Alfabeta.

[42] Sulistiyarini, Suci. Pengaruh Minat Individu Terhadap Penggunaan Mobile Banking: Model Kombinasi Technology Acceptance Model (TAM) dan Theory of Planned Behaviour (TPB). Malang: Universitas Brawijaya.

[43] Tangke, Natalia. 2004. Analisa Penerimaan Penerapan Audit Berbantuan Komputer (TABK) dengan Menggunakan Technology Acceptance Model (TAM) pada Badan Pemeriksa Keuangan (BPK) RI. Jurnal Akuntansi \& Keuangan, 6 (1): 10-28.

[44] Yuteva, Sekaran A., 2010. Analisis Pengaruh Etika Kerja Islam Terhadap Komitmen Profesi Internal Auditor, Komitmen Organisasi, dan Sikap Perubahan Organisasi (studi Empiris Terhadap Internal Auditor Perbankan Syariah di Kota Semarang dan Jakarta). Skripsi tidak diterbitkan. Semarang Fakultas Ekonomi Universitas Diponegoro. 